\title{
Red Rice Control and Soybean Tolerance to $S$-Metolachlor in Association with Glyphosate
}

\author{
Carla Rejane Zemolin, Luis Antonio de Avila*, Dirceu Agostinetto, Guilherme Vestena \\ Cassol, Marlon Bastiani, Rodrigo Pestana
}

Crop Protection Department, Federal University of Pelotas, Pelotas, Brazil

Email: laavilabr@gmail.com

Received 30 April 2014; revised 29 May 2014; accepted 20 June 2014

Copyright (C) 2014 by authors and Scientific Research Publishing Inc.

This work is licensed under the Creative Commons Attribution International License (CC BY). http://creativecommons.org/licenses/by/4.0/

(c) $\underset{\mathrm{EY}}{\mathrm{E}}$ Open Access

\section{Abstract}

Red rice is one of the major troublesome and difficult weeds to control in rice production regions. The introduction of the Clearfield ${ }^{\circledR}$ technology allowed producers to control red rice using rice genotypes tolerant to the imidazolinone herbicides. However, because the consecutive use of this technology red rice biotypes have evolved resistance to imidazolinone herbicides, the rice-soybean rotation has been an alternative used by producers to control this weed. This system allows the use of herbicides with different modes of action to control red rice, such as $S$-metolachlor. Thus, greenhouse and field experiments were carried out during the 2011 to 2012 and 2012 to 2013 growing seasons to evaluate: 1) sensitivity of imidazolinone-resistant red rice to $S$-metolachlor; 2 ) red rice control and soybean tolerance in response to associations of $S$-metolachlor and glyphosate. In greenhouse, $S$-metolachlor effectively controlled both susceptible and imidazolinone-resistant red rice in preemergence. In field, preemergence applications of $S$-metolachlor provided greater red rice control in comparison to $S$-metolachlor alone in early postemergence. The association of $S$-metolachlor with glyphosate did not improve red rice control in preemergence application. However, association of $S$-metolachlor with glyphosate significantly improved red rice control in early postemergence applications. $S$-metolachlor injury to soybean increased with early postemergence applications. These results indicate that $S$-metolachlor effectively control imidazolinone-resistant red rice in rice-soybean rotation.

\section{Keywords}

Crop Rotation, Weed Control, Crop Injury, Application Timing

\footnotetext{
*Corresponding author.
} 


\section{Introduction}

Red rice (Oryza sativa L.) is one of the major troublesome weeds of irrigated rice in the Southern Brazil and in various rice producing regions worldwide [1]-[3]. This weed belongs to the same species of cultivated rice sharing many morphological and physiological characteristics [4]. However, red rice typically exhibits seed dormancy, grows taller, and produces more tillers and biomass than cultivated rice [5]. It also has greater nitrogen efficiency under competitive conditions, absorbing up to $60 \%$ of applied $\mathrm{N}$ fertilizer [2].

Morphophysiological similarities between red rice and cultivated rice make its management difficult using conventional herbicides [6]. Since 2002, the introduction of the Clearfield ${ }^{\circledR}$ technology allowed producers to selectively control red rice in irrigated rice by using rice genotypes tolerant to the imidazolinone herbicides [7][9]. For example, the adoption of this technology resulted in more than $50 \%$ of rice acreage planted with Clearfield $^{\circledR}$ rice in Southern Brazil specifically in the state of Rio Grande do Sul by 2011 [10]. On the other hand, because the continued use of the Clearfield ${ }^{\circledR}$ rice and minimal alternative cultural practices being adopted concomitantly, several red rice biotypes have evolved resistance to the imidazolinone herbicides [10]-[12].

Facing the widespread distribution of imidazolinone-resistant red rice, rice-soybean rotation has been the most effective practice adopted by producers to control red rice, reduce seed bank and prevent rice grain yield and quality losses caused by its interference [13] [14]. In this system, glyphosate is widely used to control a broad spectrum of weeds on glyphosate-resistant soybean (GR) and it is also applied as a burndown treatment to control red rice prior to rice emergence [15] [16]. Thus, continued exposure of red rice populations to glyphosate might increase risks of resistance development to this herbicide. Related studies showed that selection pressure has already resulted in resistance to glyphosate in many other weed species [17]-[19].

Additionally, as glyphosate is a foliar-applied herbicide without soil residual activity, it must be combined with an effective soil residual herbicide or followed by a postemergence (POST) herbicide to ensure season-long weed control [20]. A common approach in soybean production is to combine glyphosate with $S$-metolachlor, applying the association before or at-planting time to control existing vegetation and provide residual weed control. S-metolachlor has demonstrated acceptable activity on annual grasses, such as barnyardgrass (Echinochloa crus-galli L.) and broadleaf sinalgrass (Urochloaplatyphylla (Griseb.) Nash), yellow nutsedge (Cyperusesculentus L.) and many small-seeded broadleaf weeds [21]. However, limited information is available concerning its efficacy on imidazolinone-resistant red rice. Thus, this study aimed to evaluate: 1) sensitivity of imidazolinone-resistant red rice biotypes to $S$-metolachlor; and 2) red rice control and soybean tolerance in response to association of $S$-metolachlor with glyphosate.

\section{Material and Methods}

\subsection{Greenhouse Study}

The experiment was carried out under greenhouse conditions at the Weed Science Research Group, Federal University of Pelotas, Capão do Leão, RS, Brazil, from October to December in 2011. The experimental design was a randomized complete block design in factorial arrangement $(4 \times 2 \times 10)$ with four replications. Factor A included four red rice biotypes, two resistant (Av75 and Av109) and two susceptible (Av01 and SC608) to the imidazolinone herbicides. Factor B was composed by two application timings (preemergence and postemergence) and factor $C$ included nine rates of $S$-metolachlor $(0.001,0.01,0.1,0.5,1.0,1.5,2.0,5.0$ and 10 -fold the recommended rate of $1680 \mathrm{~g}$ a.i ha ${ }^{-1}$ ) plus an untreated check.

Red rice biotypes were obtained from Federal University of Rio Grande do Sul, Porto Alegre, RS, Brazil. All biotypes mentioned above were collected during the 2006 to 2007 and 2007 to 2008 growing seasons in rice fields of Rio Grande do Sul. The Av109 and Av75 biotype were previously identified as imidazolinone-resistant due to ALS gene mutation Gly ${ }_{654}$ Glu [12]. Av01 and SC608 were confirmed as susceptible to imidazolinone after a screening carried out in 228 red rice populations [11].

Ten seeds of each red rice biotype were placed in $700 \mathrm{~mL}$ plastic cups previously filled with $500 \mathrm{~g}$ of lowland soil. Cups were surface irrigated every other day to allow red rice germination. Preemergence (PRE) treatments were applied after three days red rice sowing and postemergence (POST) applications at 3- to 4-leaf red rice stage. Applications were performed using a $\mathrm{CO}_{2}$-pressurized backpack sprayer coupled to a boom equipped with three flat-fan nozzles (Teejet XR110015, Spraying system Co., IL, 1609) spaced at $50 \mathrm{~cm}$ and calibrated to deliver $150 \mathrm{~L} \cdot \mathrm{ha}^{-1}$ of spray solution at $172 \mathrm{kPa}$. 
Red rice control was visually estimated at 28 days after herbicide applications using a grade from $0 \%$ to $100 \%$ where $0=$ no red rice control and $100=$ total red rice control (death of red rice plants) [22]. Plant height was determined by measuring the length $(\mathrm{cm})$ from the soil surface to the oldest leaf tip. After the final evaluation, red rice plants were harvested and dried in an oven at $60^{\circ} \mathrm{C}$ to determinate shoot dry matter. Data were expressed as percentage of untreated check to standardize comparisons between biotypes and application timings.

Red rice control, plant height and shoot dry matter were tested to assumptions of experimental design (independence, homogeneity and normality) and then subjected to analysis of variance ( $\mathrm{P} \leq 0.05)$. A non-linear loglogistic model describing by Equation (1) was used to indicate overall patterns of treatments in dose-response curves:

$$
Y=a / 1+\left(x / x_{0}\right)^{b}
$$

where $Y=$ response variable; $x=$ herbicide rate; $a=$ limiting value of red rice control on dry weight reduction; $b$ $=$ slope of the dose-response curve; $x_{0}=$ herbicide rate that provides $50 \%$ red rice control $\left(\mathrm{CT}_{50}\right) ; 50 \%$ plant height reduction $\left(\mathrm{EST}_{50}\right)$ or $50 \%$ dry weight reduction $\left(\mathrm{GR}_{50}\right)$. Ninety-five percentage confidence intervals were calculated based on standard error of estimated parameters and used to compare $\mathrm{CT}_{50}, \mathrm{EST}_{50}$ and $\mathrm{GR}_{50}$ values between biotypes.

\subsection{Field Study}

Experiments were conducted at University Farm (Centro Agropecuário da Palma), located in Capão do Leão, Rio Grande do Sul, Brazil, during the 2011 to 2012 and 2012 to 2013 growing seasons. The experimental design was a randomized complete block with four replications. Herbicide treatments included $S$-metolachlor alone or in combination with glyphosate applied both in preemergence (PRE) and early postemergence (EPOST) of soybean (Table 1). Prior to soybean planting, the SC608 red rice biotype was drilled at $2 \mathrm{~cm}$ deep at $20 \mathrm{~kg} \cdot \mathrm{ha}^{-1}$ to

Table 1. Soybean injury (\%) at 14 and 28 days after treatment applications (DAA) in the 2011 to 2012 and 2012 to 2013.

\begin{tabular}{|c|c|c|c|c|c|c|}
\hline \multirow{3}{*}{ Herbicide Treatment } & \multirow{3}{*}{$\begin{array}{c}\text { Rate } \\
\left(\mathrm{g} \cdot \mathrm{ha}^{-1}\right)\end{array}$} & \multirow{3}{*}{ Timing $^{\mathrm{a}}$} & \multicolumn{4}{|c|}{ Soybean injury (\%) ${ }^{\mathrm{b}}$} \\
\hline & & & \multicolumn{2}{|c|}{2011 to 2012} & \multicolumn{2}{|c|}{2012 to 2013} \\
\hline & & & 14 DAA & $28 \mathrm{AA}$ & 14 DAA & 28 DAA \\
\hline$S$-metolachlor & 768 & PRE & 5 & 5 & 10 & 5 \\
\hline$S$-metolachlor & 1152 & PRE & 8 & 5 & 12 & 3 \\
\hline$S$-metolachlor & 1680 & PRE & 10 & 5 & 12 & 5 \\
\hline$S$-metolachlor + glyphosate & $768+1860$ & PRE & 5 & 5 & 8 & 3 \\
\hline$S$-metolachlor + glyphosate & $1152+1860$ & PRE & 6 & 5 & 11 & 4 \\
\hline S-metolachlor + glyphosate & $1680+1860$ & PRE & 6 & 5 & 13 & 5 \\
\hline$S$-metolachlor & 768 & EPOST & 15 & 5 & 7 & 9 \\
\hline$S$-metolachlor & 1152 & EPOST & 20 & 7 & 20 & 10 \\
\hline$S$-metolachlor & 1680 & EPOST & 27 & 9 & 17 & 8 \\
\hline$S$-metolachlor + glyphosate & $768+1860$ & EPOST & 14 & 5 & 12 & 6 \\
\hline S-metolachlor + glyphosate & $1152+1860$ & EPOST & 18 & 6 & 15 & 7 \\
\hline$S$-metolachlor + glyphosate & $1680+1860$ & EPOST & 18 & 6 & 16 & 5 \\
\hline Untreated check & - & - & N/A & N/A & N/A & N/A \\
\hline LSD (0.05) & - & - & 5 & 2 & 8 & 4 \\
\hline
\end{tabular}

${ }^{a}$ Abbreviation: PRE, preemergence; EPOST, early postemergence. ${ }^{b}$ Data were presented as a percent of soybean injury compared with the untreated check (no herbicide). 
ensure properly red rice infestation in the experimental area. An early-maturity variety (FUNDACEP 62 GR) was drill seeded perpendicularly to red rice rows at 400,000 seeds per hectare in December for both growing seasons. Soybean was planted in $45 \mathrm{~cm}$ row spacings. Seeds were previously inoculated with Bradyrhizobium japonicum SEMIA 5079 (CPAC 15) and SEMIA 5080 (CPAC 7) strains to provide biological nitrogen fixation. Soybean plots measured $4 \mathrm{~m}$ long and $2 \mathrm{~m}$ wide. All the other agronomic practices followed local recommendations for soybean production [23].

Treatment applications were performed with a $\mathrm{CO}_{2}$-pressurized backpack sprayer coupled to a boom equipped with three flat-fan nozzles (Teejet XR11002, Spraying system Co., IL, 1609) spaced at $50 \mathrm{~cm}$ and calibrated to deliver $150 \mathrm{~L} \cdot \mathrm{ha}^{-1}$ of spray solution at $172 \mathrm{kPa}$. Red rice control and herbicide injury to soybean were estimated visually at 14 and 28 days after herbicide applications (DAA). Visual ratings were based on a grade from 0 to $100 \%$ where $0=$ no herbicide injury symptoms or red rice control and $100=$ total herbicide injury (death of soybean plants) or red rice control [22].

Data were tested to assumptions of experimental design (independence, homogeneity and normality) and followed by analysis of variance $(\mathrm{P} \leq 0.05)$. Means of significant main effects were separated by Fisher's protected LSD test $(\mathrm{P} \leq 0.05)$.

\section{Results and Discussion}

\subsection{Greenhouse Study}

According to analysis of variance, there was no significant effect of biotype $(\mathrm{P} \geq 0.05)$ for all of the variables evaluated in the experiment. This indicates that both imidazolinone-resistant and imidazolinone-susceptible biotypes showed similar sensitivity to $S$-metolachlor and therefore data were pooled across biotypes to generate the dose-response curves.

Differences on $\mathrm{CT}_{50}, \mathrm{EST}_{50}$ and $\mathrm{GR}_{50}$ were observed between application timings. Preemergence (PRE) application of $S$-metolachlor provided greater red rice control (Figure $1(\mathrm{~A})$ ). Lower $S$-metolachlor rate was required to achieve 50\% red rice control in PRE compared to POST application. Similar tendency was verified to plant height variable (Figure $1(B)$ ). Only the $\mathrm{GR}_{50}$ value was lower for POST in comparison to PRE application (Figure 1(C)). Greater $S$-metolachlor efficacy on red rice in PRE application may be also related to its mode of action, which inhibits the biosynthesis of several plant components such as fatty acids, lipids, proteins, isoprenoids and flavonoids [24]. S-metolachlor is primarily absorbed by emerging shoots, especially grass coleoptiles whereas weeds beyond the seedling stage can absorb the herbicide by the root system and translocate to the shoots, but its translocation is limited [24]. Thus, these characteristics enhance S-metolachlor efficacy in younger weeds. Related studies have been reported greater annual grasses control when $S$-metolachlor was PRE applied in corn, soybean and dry bean [21]-[25].

\subsection{Field Study}

Herbicide injury to soybean was $27 \%$ or less in both years of experiment. Early postemergence (EPOST) applications of $S$-metolachlor plus glyphosate or $S$-metolachlor alone increased herbicide injury to soybean at 14 DAA in 2011 to 2012 and 2012 to 2013 growing seasons (Table 1). In this study the symptoms of soybean injury were similar to the symptoms observed by Clewis et al. (2006) [26], mainly characterized by growth reduction and transient necrotic speckling on exposed leaves. Increased injury with EPOST applications may be related to direct exposure of soybeans leaves to $S$-metolachlor reducing plant ability to overcome the oxidative stress caused by herbicide application.

Red rice control was significantly affected by application timing and association of herbicides. $S$-metolachlor rate had little effect on red rice control regardless of the association with glyphosate (Table 2). Poor red rice control was obtained when $S$-metolachlor was applied alone in EPOST applications. In contrast, PRE applications of $S$-metolachlor alone significantly improved red rice control in both years of experiment. Greater $S$-metolachlor efficacy in PRE applications might be related to the fact that red rice plants can easily absorb and translocate the herbicide during the germination and early growth stages.

Association with glyphosate in PRE applications did not improve red rice control in comparison to $S$-metolachlor alone. However, EPOST applications of $S$-metolachlor plus glyphosate resulted in greater red rice control at 28 DAA in 2011 to 2012 and 2012 to 2013 growing seasons (Table 2). The efficacy of this associa 


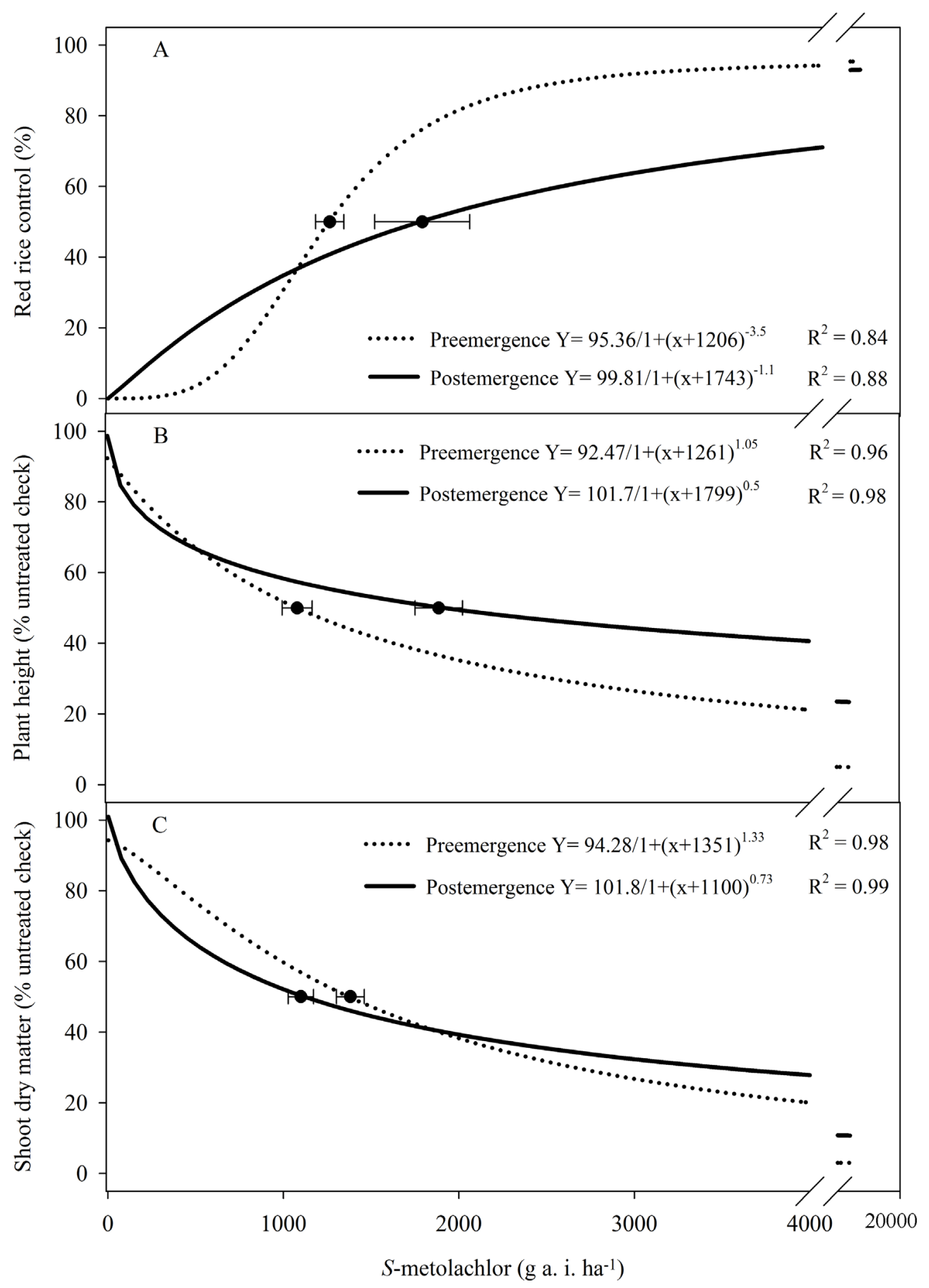

Figure 1. Red rice control (A), plant height (B) and shoot dry matter (C) in response to rates and application timings of $S$-metolachlor at 28 days after treatment applications. Errors bars represent $95 \%$ confidence intervals of four replications.

tion in EPOST applications may be explained by a combination of factors. Glyphosate is a postemergence nonselective herbicide that controls many annual and perennial weeds. It is particularly very active on annual grasses such as barnyard grass, broadleaf signal grass and red rice [15]-[27]. As a result, POST applications of glyphosate ensured almost total control of the existing red rice in this study. In addition, association with $S$-me- 
Table 2. Red rice control (\%) at 14 and 28 days after treatment applications (DAA) in the 2011 to 2012 and 2012 to 2013.

\begin{tabular}{|c|c|c|c|c|c|c|}
\hline \multirow{3}{*}{ Herbicide Treatment } & \multirow{3}{*}{$\begin{array}{c}\text { Rate } \\
\left(\mathrm{g} \cdot \mathrm{ha}^{-1}\right)\end{array}$} & \multirow{3}{*}{ Timing $^{\mathrm{a}}$} & \multicolumn{4}{|c|}{ Red rice control (\%) } \\
\hline & & & \multicolumn{2}{|c|}{2011 to 2012} & \multicolumn{2}{|c|}{2012 to 2013} \\
\hline & & & 14 DAA & $28 \mathrm{AA}$ & 14 DAA & $28 \mathrm{DAA}$ \\
\hline$S$-metolachlor & 768 & PRE & 65 & 74 & 82 & 53 \\
\hline$S$-metolachlor & 1152 & PRE & 69 & 79 & 72 & 55 \\
\hline$S$-metolachlor & 1680 & PRE & 65 & 84 & 90 & 64 \\
\hline$S$-metolachlor + glyphosate & $768+1860$ & PRE & 56 & 84 & 90 & 79 \\
\hline S-metolachlor + glyphosate & $1152+1860$ & PRE & 70 & 91 & 89 & 74 \\
\hline S-metolachlor + glyphosate & $1680+1860$ & PRE & 68 & 87 & 98 & 95 \\
\hline$S$-metolachlor & 768 & EPOST & 0 & 0 & 23 & 23 \\
\hline$S$-metolachlor & 1152 & EPOST & 0 & 0 & 28 & 20 \\
\hline$S$-metolachlor & 1680 & EPOST & 0 & 0 & 33 & 27 \\
\hline S-metolachlor + glyphosate & $768+1860$ & EPOST & 96 & 99 & 97 & 96 \\
\hline$S$-metolachlor + glyphosate & $1152+1860$ & EPOST & 98 & 100 & 98 & 98 \\
\hline S-metolachlor + glyphosate & $1680+1860$ & EPOST & 98 & 100 & 98 & 98 \\
\hline Untreated check & - & - & N/A & N/A & N/A & N/A \\
\hline $\operatorname{LSD}(0.05)$ & - & - & 11 & 9 & 16 & 22 \\
\hline
\end{tabular}

${ }^{a}$ Abbreviation: PRE, preemergence; EPOST, early postemergence. ${ }^{\mathrm{b}}$ Data were presented as a percent of red rice control compared with the untreated check (no herbicide).

tolachlor provided residual activity in soil preventing red rice emergence throughout the soybean growing season.

\section{Conclusion}

These results indicate that PRE applications of $S$-metolachlor effectively control imidazolinone-resistant red rice. The association of $S$-metolachlor with glyphosate does not improve red rice control in PRE applications. However, associations of $S$-metolachlor with glyphosate significantly improve red rice control in EPOST applications. Soybean injury increases in EPOST applications but is less than 10\% at 28 days after herbicide application.

\section{Acknowledgements}

The authors gratefully acknowledge the financial support of Conselho Nacional de Desenvolvomento Científico e Tecnológico (CNPq). They also would like to acknowledge the Environmental Fate of Herbicides team for the assistance with this research.

\section{References}

[1] Agostinetto, D., Fleck, N.G., Rizzardi, M.A., Merotto Jr., A. and Vidal, R.A. (2001) Red Rice: Ecophysiology and Strategies of Control. Ciência Rural, 31, 341-349. http://dx.doi.org/10.1590/S0103-84782001000200026

[2] Burgos, N.R., Norman, R.J., Gealy, D.R. and Black, H. (2006) Competitive N Uptake between Rice and Weedy Rice. Field Crops Research, 99, 96-105. http://dx.doi.org/10.1016/j.fcr.2006.03.009

[3] Souza, P.R. and Fischer, M.M. (1986) Red Rice: Yield Losses in the Rice Fields of Southern Brazil. Lavoura Arrozeira, 39, 19-20.

[4] Eleftherohorinos, I.G. and Dhima, K.V. (2002) Red Rice (Oryza sativa) Control in Rice (O. sativa) with Preemergence 
and Postemergence Herbicides. Weed Technology, 16, 537-540. http://dx.doi.org/10.1614/0890-037X(2002)016[0537:RROSCI]2.0.CO;2

[5] Estorninos Jr., L.E., Gealy, D.R., Gbur, E.E., Talbert, R.E. and Mcclelland, M.R. (2005) Rice and Red Rice Interference. II. Rice Response to Population Densities of Three Red Rice (Oryza sativa) Ecotypes. Weed Science, 53, 683689. http://dx.doi.org/10.1614/WS-04-040R1.1

[6] Fogliatto, S., Vidotto, F. and Ferrero, A. (2011) Morphological Characterization of Italian Weedy Rice (Oryza sativa) Populations. Weed Research, 52, 60-69. http://dx.doi.org/10.1111/j.1365-3180.2011.00890.x

[7] Avila, L.A., Senseman, S.A.G., Mccauley, N., Chandler, J.M. and O’Barr, J.H. (2005) Effect of Flood Timing on Red Rice (Oryza spp.) Control with Imazethapyr Applied at Different Dry-Seeded Rice Growth Stages. Weed Technology, 19, 476-480. http://dx.doi.org/10.1614/WT-04-181

[8] Steele, G.L., Chandler, J.M. and Mccauley, G.N. (2002) Control of Red Rice (Oryza sativa) in Imidazolinone-Tolerant Rice (O. sativa). Weed Technology, 16, 627-630. http://dx.doi.org/10.1614/0890-037X(2002)016[0627:CORROS]2.0.CO;2

[9] Villa, S.C.C., Marchesan, E., Massoni, P.F.S., Santos, F.M., Avila, L.A. and Telo, G.M. (2006) Red Rice Control in Two Rice (Oryza sativa) Genotypes Tolerant to Imidazolinone Herbicides. Planta Daninha, 24, 549-555. http://dx.doi.org/10.1590/S0100-83582006000300018

[10] Andres, A., Theisen, G., Concenço, G. and Galon, L. (2013) Weed Resistance to Herbicides in Rice Fields in Southern Brazil. In: Price, A.J. and Kelton, J.A., Eds., Herbicides-Current Research and Case Studies in Use, InTech, Rijeka. 3-25.

[11] Menezes, V.G., Mariot, C.H.P., Kalsing, A. and Goulart, I.C.G.R. (2009) Red Rice (Oryza sativa) Resistant to the Herbicides Imidazolinones. Planta Daninha, 27, 1047-1052. http://dx.doi.org/10.1590/S0100-83582009000500018

[12] Roso, A.C., Merotto Jr., A. and Delatorre, C.A. (2010) Bioassays for Diagnosis of Resistance to the Herbicides Imidazolinones in Rice Plants. Planta Daninha, 28, 411-419. http://dx.doi.org/10.1590/S0100-83582010000200021

[13] Avila, L.A., Marchezan, E., Machado, S.L.O. and Silva, R.P. (2000) Red Rice Seed Bank Evolution under Different Systems of Lowland Utilization. Planta Daninha, 18, 217-230.

[14] Burgos, N.R., Norsworthy, J.K., Scott, R.C. and Smith, K.L. (2008) Red Rice (Oryza sativa) Status after 5 Years of Imidazolinone-Resistant Rice Technology in Arkansas. Weed Technology, 22, 200-208. http://dx.doi.org/10.1614/WT-07-075.1

[15] Burgos, N.R., Shivrain, V.K., Scott, R.C., Mauromoustakos, A., Kuk, Y.I., Sales, M.A. and Bullington, J. (2011) Differential Tolerance of Weedy Red Rice (Oryza sativa L.) from Arkansas, USA to Glyphosate. Crop Protection, 30, 986-994. http://dx.doi.org/10.1016/j.cropro.2011.03.024

[16] Sartori, G.M.S., Marchesan, E., Azevedo, C.F., Filho, A.C., Roso, R., Coelho, L.L. and Oliveira, M.L. (2013) Effects of Irrigated Rice Sowing Season and Imazapyr + Imazapic Time of Application on Rice Grain Yield and Red Rice Management. Planta Daninha, 31, 631-644. http://dx.doi.org/10.1590/S0100-83582013000300015

[17] Jasieniuk, M.R., Ahmad, A.M., Sherwood, J., Firestone, L., Perez-Jones, A., Lanini, W.T., Mallory-Smith, C.A. and Stednick, Z. (2008) Glyphosate-Resistant Italian Ryegrass (Lolium multiflorum) in California: Distribution, Response to Glyphosate and Molecular Evidence for an Altered Target Enzyme. Weed Science, 54, 496-502. http://dx.doi.org/10.1614/WS-08-020.1

[18] Kaundun, S.S., Zelaya, I.A., Dale, R.P., Lycett, A.J., Carter, P., Sharples, K.R. and McIndoe, E. (2008) Importance of the P106S Target-Site Mutation in Conferring Resistance to Glyphosate in a Goosegrass (Eleusine indica) Population from the Philippines. Weed Science, 56, 637-646. http://dx.doi.org/10.1614/WS-07-148.1

[19] Simarmata, M. and Penner, D. (2008) The Basis for Glyphosate Resistance in Rigid Ryegrass (Lolium rigidum) from California. Weed Science, 56, 181-188. http://dx.doi.org/10.1614/WS-07-057.1

[20] Corrigan, K.A. and Harvey, R.G. (2000) Glyphosate with and without Residual Herbicides in No-Till Glyphosate-Resistant Soybean (Glycine max). Weed Technology, 14, 569-577. http://dx.doi.org/10.1614/0890-037X(2000)014[0569:GWAWRH]2.0.CO;2

[21] O’Connell, P.J., Harms, C.T. and Allen, J.R.F. (1998) Metolachlor, S-Metolachlor and Their Role within Sustainable Weed Management. Crop Protection, 17, 207-212. http://dx.doi.org/10.1016/S0261-2194(98)80011-2

[22] Frans, R., Talbert, R., Marx, D. and Crowley, H. (1986) Experimental Design and Techniques for Measuring and Analyzing Plant Responses to Weed Control Practices. In: Camper, N.D., Ed., Southern Weed Science Society, Research Methods in Weed Science, 3rd Edition, WSSA, Champaign, 29-46.

[23] Embrapa (2009) Meeting of Soybean Research in the Southern Region. 37th Edition, Embrapa Trigo, Porto Alegre, $144 \mathrm{p}$.

[24] Senseman, S.A. (2007) Herbicide Handbook. 9th Edition, Weed Science Society of America, Lawrence, 275-278. 
[25] Lamego, F.P., Basso, C.J., Vidal, R.A., Trezzi, M.M., Santi, A.L., Ruchel, Q., Kaspary, T.E. and Gallon, M. (2011) Selectivity of Metolachlor and Alachlor for the “Carioca” Bean. Planta Daninha, 29, 877-883. http://dx.doi.org/10.1590/S0100-83582011000400018

[26] Clewis, S.B., Wilcut, J.W. and Porterfield, D. (2006) Weed Management with S-Metolachlor and Glyphosate Mixtures in Glyphosate-Resistant Strip- and Conventional-Tillage Cotton (Gossypium hirsutum L.). Weed Technology, 20, 232241. http://dx.doi.org/10.1614/WT-05-030R.1

[27] Ellis, J.L. and Griffin, J.M. (2002) Glyphosate and Broadleaf Herbicide Mixtures for Soybean (Glycine max). Weed Technology, 17, 21-27. http://dx.doi.org/10.1614/0890-037X(2003)017[0021:GABHMF]2.0.CO;2 
Scientific Research Publishing (SCIRP) is one of the largest Open Access journal publishers. It is currently publishing more than 200 open access, online, peer-reviewed journals covering a wide range of academic disciplines. SCIRP serves the worldwide academic communities and contributes to the progress and application of science with its publication.

Other selected journals from SCIRP are listed as below. Submit your manuscript to us via either submit@scirp.org or Online Submission Portal.
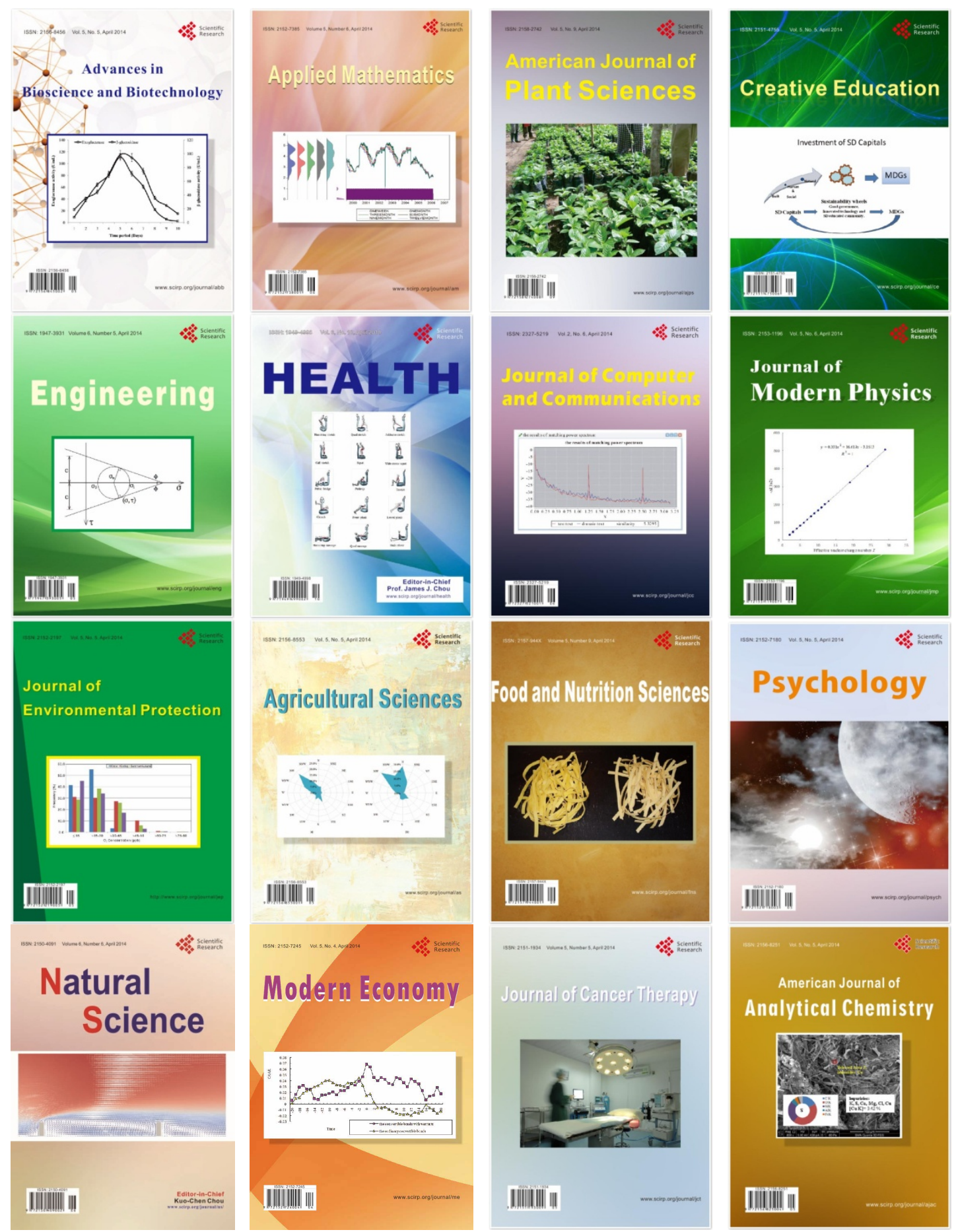